\title{
Revisiting Rogers: the diffusion of his innovation development process as a normative framework for innovation managers, students and scholars
}

\author{
Angèle M. Beausoleil \\ angele.beausoleil@rotman.utoronto.ca | Rotman School of Management, 105 St. George St., Toronto, \\ ON M5S 3E6 Canada
}

\begin{abstract}
Innovation has evolved into a core management function for most organizations. Business managers, regardless of sector or firm size, now require an understanding of and practice with the innovation process in order to develop a competence with navigating its winding path. To effectively engage in innovation processes, individuals require a distinct set of knowledge, aptitude and skills, or key innovative competencies. This paper examines a broad multidisciplinary literature focused on how innovation happens and the normative elements of its process, to inform key innovative competencies across its many phases. Through document analysis, empirically-based innovation process theories and models are examined with the intent to discover and propose a normative framework. The literature review provides a broad classification of innovation process descriptions and phases reflecting Everett Rogers' original innovation-development process (IDP). Rogers' IDP is proposed as a normative framework from which individual innovative competencies are identified and classified. Both the framework and typology are proposed as guides for innovation process understanding, participation and management. For innovation researchers and educators, this article suggests an innovation process normative framework may act as a recipe for further research on innovative competencies and innovation management pedagogical models.
\end{abstract}

Keywords. Innovation development process; Normative framework; Individual innovative competencies; Innovation management; Innovativeness, E. Rogers.

Cite paper as: Beausoleil, A., (2018). Revisiting Rogers: the diffusion of his innovation development process as a normative framework for innovation managers, students and scholars, Journal of Innovation Management, www.open-jim.org, 6(4), 73-97. http://hdl.handle.net/10216/118596; DOI: https://doi.org/10.24840/21830606_006.004_0006 


\section{Introduction}

Innovation management generally encompasses knowledge required to master the initiation, development and commercialization of successful products and services (Liyanage and Poon, 2002). Most innovation management research has focused on new product development processes, product innovation, product technology, pricing and market adoption (Montoya-Weiss and Calantone, 1994; Yang and Tao, 2012). However, few studies have explored topics such as individual innovation process managers, organizational factors and management teams (Montoya-Weiss and Calantone, 1994; Thieme, 2007; Yang and Tao, 2012). To date, innovation management education typically reflects scholarly research preferences, leaving gaps in the studies focused on innovation process models, and associated innovative competencies. This article nudges innovation management scholars and educators to engage in more research and translation of the comprehensive innovation process, particularly on the fuzzy front-end or initiation phase. It is through the lens of the process itself where the individual is the central actor, not the idea or innovation.

Innovation is deemed critical for organizational growth and survival. However, for innovation managers, the risk and uncertainty surrounding its process and practice is omnipresent. Innovation doesn't just happen, it is socially constructed. Individuals and organizations construct mechanisms for the development of new ideas through cultural or social practice. The innovation process is actually designed by individuals, teams and social systems, implicitly or explicitly, yet is perceived as highly complex. This article is written in response to this need for clearer understanding of the innovation process, and its associated competencies for effective management. The paper offers a normative framework to guide business schools to reflect on their innovation management pedagogy, to provoke innovation scholars to consider pre-diffusion analytical models, and to offer business managers a way to navigate its complexity.

The innovation process has been extensively studied across academic disciplines and industry practices, however this paper presents a literature review and analysis of its theoretical and empirical process models, with the aim to inform a normative framework as a guide to understanding innovation's critical phases. I propose it is by first reflecting on the normative insights of it process, individual innovative competencies can be studied and compared and navigating its complexity better understood.

This article suggests that in order to provide innovation management knowledge and a discussion on innovative competence, we should shift some research onto understanding its process and toward long-term performance outcomes. A normative framework is thus needed to inform how innovation process participants should behave in order to engage in its inputs and outcomes. For this paper, a normative framework refers to a model that reflects the thinking of shared norms, values, and trade-offs (Bicchieri, 2005) as deemed useful in organizational contexts.

A select innovation process literature, with the intent to propose a normative framework of the innovation development process, is examined through document analysis. The data collected from the document analysis offers a classification of seminal innovation process theories from the past 100 years, and a contemporary review of innovation process phases, key activities and models. The analysis involves the re-examination of a seminal and rigorous innovation-development 
theory (Rogers 1962-2010), and the proposition of a normative framework as a way to identify innovative competencies for individuals participating in an innovation process.

The key finding recommends a normative framework that is not a new framework, instead it is new interpretation of Everett Rogers' innovation-development process introduced between 1962 and 1983 (Rogers, 1962-2010). It is re-presented as a guide or recipe for the design and evaluation of a typical innovation process. This framework is then used to explore and identify key individual innovative competencies associated with critical actions and decisions made along the innovation process journey. Both the normative framework and associated innovative competencies typology are proposed as concepts for further research of innovation management, organizational innovation pedagogy and practice.

The paper offers: (1) an introduction to article's intent, research method and key findings; (2) a multidisciplinary innovation process literature review; the innovation process and organizations; how innovation happens; a systematic review of innovation process models; and, revisiting E. Rogers innovation-development process; (3) a mapping of innovative competencies across a normative framework; (4) a discussion and conclusions; (5) the limitations of analysis; and, (6) references.

\subsection{Research method}

The research method for this article involved a document analysis of multidisciplinary innovationprocess focused literature. Document analysis provided a systematic approach for reviewing, evaluating and interpreting documents. It is a well-practiced analytical method in qualitative research which entails finding, selecting, analyzing and synthesizing data contained in documents (Yin, 1994). Document analysis is selected for this article as it involves collection of rich descriptions of a single phenomenon or program, in this case, the innovation process. As a qualitative research method, it aims to elicit meaning, gain understanding, and develop empirical knowledge from the related data (Corbin \& Strauss, 2008; Rapley, 2007; Bowen, 2009).

The documents found and selected for this paper comprised of innovation process process theories and model literature that span over 100 years and across multiple disciplines. The selected documents are empirical-evidence based published academic articles, books, and professional working papers. The data analysis involved: revisiting past innovation process models and examining recent contemporaries; categorizing key innovation development process phases; and, classifying individual innovative competencies associated with each process phase. The unit of analysis for the innovation-process competencies is the individual or individual member participating in an innovation process. The findings from this analysis offer some evidence that Roger's innovationdevelopment process has been diffused and adopted; that as a normative process framework, it can be translated into a model for future research particularly to investigate individual innovative competenies. Such action-research studies may be valuable in the design and delivery of management school pedagogies concerning innovation management.

\section{A multidisciplinary innovation process literature review}

The innovation process literature is vast, multi-disciplinary and spans over 100 years. Sociologist 
Gabriel Tarde (1903) was the first to describe the innovation process as an observable and repeatable process of human imitation. He described how individuals and societies imitate behaviours of others, recombining their own values and desires, and then expressing them in new forms or 'inventions'. Economist Joseph Schumpeter (1934) argued the innovation process involves a science-push and problem-solving methodology, and is focused on tangible products and processes that can be measured economically. Godin (2006) offers a well-researched historical account of scientific and economic models of innovation, acknowledging natural scientist (V.Bush, 1945) and management science researchers (Dearborn, Kneznek, \& Anthony, 1953), as influencing a linear model of the innovation process, adopted extensively by the National Research Foundation and the Organization for Economic Co-operation and Development (OECD). Godin summarized the linear model as serving as an analytical framework and corresponding to policy preoccupations and economic priorities. This multi-disciplinary model comprised three steps: basic research (for the public support to university research); applied research and development (the strategic importance of technology for industry); and, diffusion (measuring the impact of research on the economy and society) (Godin, 2006:659). Communication scholar and sociologist, Everett Rogers (1962) introduced an extensive body of work on the innovation process through his Diffusion of Innovationstheory. His theory detailed numerous innovation process models and frameworks for organizations, systems and individuals. His innovation process comprised of: an innovation, as an idea, practice or object that is perceived as new by an individual or other unit of adoption; communication channels, as the means by which messages about the innovation move from one individual to another; time, a unit that measures the duration of innovation-decision process itself, how long it takes for the innovation to be adopted by an individual or group, and the innovation's rate of adoption; and, social system, a set of interrelated units that are engaged in joint problem solving to accomplish a common goal (Rogers 1962, 1993, 1995).

Design engineer scholar Rolf Faste (1987) proposes the innovation process engages ambidextrous thinking for a more balanced and potent approach to problem solving. Organization scholar Andrew Van de Ven (1999) proposed the innovation process is a journey along an uncharted river, led by individuals with ambiguous goals, who display divergent and convergent behaviours. Psychology scholar José Fonseca (2002) argues the innovation process is a form of social relation between people, and is fundamentally a conversational process.

The table below highlights a small sample of the innovation process literature reviewed. The corpus of literature was first identified by the author(s)' purpose to examine, interpret and provide emperical knowledge of the innovation process. The literature was then recategorized based on citations, suggesting one form of measure of 'knowledge adoption'. The documents were collected from an extensive academic journal database search involving two keyword phases: "innovation process" and "innovation as a process"; and with a minimum citation rank of 1,000. The minimum numerical value of citations reflects a self-imposed constraint for this article on influential studies. A minimum level of citations suggests an effective diffusion of the innovation research knowledge to both scholars and practitioners. 
Table 1. Most cited literature on the innovation process.

\begin{tabular}{|c|c|c|c|}
\hline Humanities & $\begin{array}{l}\text { Social Sciences: } \\
\text { Economics Sociology }\end{array}$ & / Anthropology & Sciences \\
\hline $\begin{array}{l}\text { Tarde, G. (1903). } \\
\text { The laws of } \\
\text { imitation. H. Holt. }\end{array}$ & $\begin{array}{l}\text { Schumpeter, J. A. } \\
\text { (1934). The theory of } \\
\text { economic development: } \\
\text { An inquiry into profits, } \\
\text { capital, credit, interest, } \\
\text { and the business cycle } \\
\text { (Vol. 55). Transaction } \\
\text { publishers. }\end{array}$ & $\begin{array}{l}\text { Burns, T. E., \& } \\
\text { Stalker, G. M. (1961). } \\
\text { The management of } \\
\text { innovation. University } \\
\text { of Illinois. Academy } \\
\text { for Entrepreneurial } \\
\text { Leadership Historical } \\
\text { Research Reference in } \\
\text { Entrepreneurship. }\end{array}$ & $\begin{array}{l}\text { Gabor, D. (1970). } \\
\text { Innovations: Scientific, } \\
\text { Technological, and } \\
\text { Social. And Gabor, D. } \\
\text { (1946). Theory of } \\
\text { communication. Part } \\
\text { 1: The analysis of } \\
\text { information. Journal } \\
\text { of the Institution of } \\
\text { Electrical Engineers. } \\
\text { 93(26), 429-441. }\end{array}$ \\
\hline $\begin{array}{l}\text { H. G. Barnett } \\
\text { (1953). Innovation: } \\
\text { The Basis of } \\
\text { Cultural Change } \\
\text { (New York: } \\
\text { McGraw-Hill Book } \\
\text { Company. }\end{array}$ & $\begin{array}{l}\text { Usher, A.P. (1954) A } \\
\text { History of Mechanical } \\
\text { Inventions. Harvard } \\
\text { University Press. }\end{array}$ & $\begin{array}{l}\text { Rogers, E. M. } \\
(1962-2010) \text {. Diffusion } \\
\text { of innovations. Simon } \\
\text { and Schuster }\end{array}$ & $\begin{array}{l}\text { Abernathy, W. J., \& } \\
\text { Utterback, J. M. } \\
\text { (1978). Patterns of } \\
\text { industrial innovation. } \\
\text { Technology review (64) } \\
\text { 254-228. }\end{array}$ \\
\hline $\begin{array}{l}\text { Hagerstrand, T. } \\
\text { (1968). Innovation } \\
\text { diffusion as a spatial } \\
\text { process. University } \\
\text { of Chicago Press. }\end{array}$ & $\begin{array}{l}\text { Pareto, V. (1964). } \\
\text { Cours d'économie } \\
\text { politique. Librairie } \\
\text { Droz. Pareto, V. } \\
\text { (1971). Manual of } \\
\text { political economy. }\end{array}$ & $\begin{array}{l}\text { Van de Ven, A. H. } \\
(1986) . \text { Central } \\
\text { problems in the } \\
\text { management of } \\
\text { innovation. } \\
\text { Management } \\
\text { Science, } 32(5), 590-607\end{array}$ & $\begin{array}{l}\text { Simon, H. A. (1996). } \\
\text { The sciences of the } \\
\text { artificial. MIT press. }\end{array}$ \\
\hline $\begin{array}{l}\text { Moore, G. A. } \\
\text { (2002). Crossing } \\
\text { the chasm. Harper } \\
\text { Publications. }\end{array}$ & $\begin{array}{l}\text { Kline, S. J., \& } \\
\text { Rosenberg, N. (1986). } \\
\text { An overview of } \\
\text { innovation. The } \\
\text { positive sum strategy: } \\
\text { Harnessing technology } \\
\text { for economic growth } \\
\text { (14) } 640 .\end{array}$ & $\begin{array}{l}\text { Brown, J. S., \& } \\
\text { Duguid, P. (1991). } \\
\text { Organizational } \\
\text { learning and } \\
\text { communities-of- } \\
\text { practice: Toward a } \\
\text { unified view of } \\
\text { working, learning, and } \\
\text { innovation. } \\
\text { Organization } \\
\text { science, } 2(1), 40-57 . \\
\end{array}$ & \\
\hline $\begin{array}{l}\text { Christensen, C. } \\
\text { (2013). The } \\
\text { innovator's } \\
\text { dilemma: when new } \\
\text { technologies cause } \\
\text { great firms to fail. } \\
\text { HBR Press. }\end{array}$ & $\begin{array}{l}\text { Nelson, R. R. (Ed.). } \\
\text { (1993). National } \\
\text { innovation systems: a } \\
\text { comparative analysis. } \\
\text { Oxford university } \\
\text { press. }\end{array}$ & $\begin{array}{l}\text { Rothwell, R. (1994). } \\
\text { Towards the } \\
\text { fifth-generation } \\
\text { innovation process. } \\
\text { International } \\
\text { marketing review, } \\
\text { 11(1), 7-31. }\end{array}$ & \\
\hline
\end{tabular}




\begin{tabular}{|c|c|c|c|}
\hline Humanities & $\begin{array}{l}\text { Social Sciences: } \\
\text { Economics Sociology }\end{array}$ & / Anthropology & Sciences \\
\hline \multirow[t]{3}{*}{$\begin{array}{l}\text { Drucker, P. (2014). } \\
\text { Innovation and } \\
\text { entrepreneurship. } \\
\text { Routledge. }\end{array}$} & $\begin{array}{l}\text { Freeman, C., \& Soete, } \\
\text { L. (1997). The } \\
\text { economics of industrial } \\
\text { innovation. } \\
\text { Psychology Press. }\end{array}$ & $\begin{array}{l}\text { Gardner, J. W. (1995). } \\
\text { Self-renewal: The } \\
\text { individual and the } \\
\text { innovative society. } \\
\text { WW Norton \& } \\
\text { Company. }\end{array}$ & \\
\hline & $\begin{array}{l}\text { Von Hippel, E. A. } \\
\text { (2005). Democratizing } \\
\text { innovation. }\end{array}$ & & \\
\hline & $\begin{array}{l}\text { Chesbrough, H. W. } \\
\text { (2006). Open } \\
\text { innovation: The new } \\
\text { imperative for creating } \\
\text { and profiting from } \\
\text { technology. Harvard } \\
\text { Business Press. }\end{array}$ & & \\
\hline
\end{tabular}

\subsection{The innovation process and organizations}

For organizations, Van de Ven defines the innovation process as a facilitated approach to creativity, and successful management of the complex process of turning creative ideas into reality (Van de Ven, 1999). Chaput (2011) argues innovation is a change management process. He proposes that where the capacity for change is a requirement for innovation, the main task is to lead a group towards a given direction different from the observed one, knowing people would prefer other options; that this group decides to cooperate and move towards an end, and that tools are provided to exercise this will to cooperate (Chaput, 2011). Manzini (2003) proposes that the innovation process is actually a short-term strategic process, which results in new forms of organization and innovative forms of co-production of value. Amabile et al (1996) and Damanpour et al (1984) propose the innovation process is the development, adaptation and implementation of an idea that is useful and new to the organization at the time of adoption. Christensen (1997) associates the innovation process with disruptive technologies leading to disruptive innovations. Akrich and Fonseco et al (2002) argue innovation is potentially a new patterning of everyday experiences, a responsive and generative process resulting in sense-making and new meanings. To summarize, the broad innovation process discourse offers a diversity of ideologies that in fact, share common actors and agents. They include individuals, individual and system-based processes, and outputs (i.e. innovations). Simply put, the innovation process described across disciplines contain similar ingredients, however their recipes may differ.

\subsection{The innovation process recipe: toward a normative framework}

The most common innovation process 'recipe' is described as a phased or stage-based approach. 
This recipe describes phases as steps on how to prepare or make something, in this case an innovation. The value of a recipe is that it offers a simplified construct and affords individuals a sense of orientation when it comes to decision-making, and organizations a sense of thinking about allocation of research resourcing, funding, production, and distribution. Godin (2006) might agree with this notion that the value of an innovation process as recipe, could also support comparative and statistical studies "often required to give (long) life to concepts" (Godin, 2006).

Although many scholars argue there is not one universal or exact sequence of steps to the innovation process, most agree on four key activities, those involving the initial vision or input, idea generation, innovation development, and implementation or output (Amabile, 1988:151). Many researchers (Marcus, 1988; Rogers, 1983; Staw, 1990; Zaltman, Dun, and Holbec 1973) have supported a general two-stage model: (1) an initiation stage, which consists of "all activities pertaining to problem perception information gathering, attitude formation and evaluation, and resource attainment leading to the decision to adopt"; and (2) an implementation stage which consists of "all events and actions pertaining to modifications to the innovation and/or organization, initial utilization, and continued use or discontinued use (Damanpour, 1991:562). Van de Ven et al (1999) argue the innovation process is comprised of three phases: (1) an initiationperiod comprised of events that set the stage for launching the efforts of developing the innovation; (2) a developmentalperiod comprised of activities and efforts undertaken to transform the innovation idea into a concrete reality; and (3) an implementationperiod which comprises of innovation adopted as a new program, product or business or terminated and abandoned. Their framework reflects the common elements empirically derived from his studies of the innovation journey. They separate the developmentphase from the implementation phase as it engages in a messy, chaotic and series of events.

The innovation process models are critical to understand, because they break down the innovation process into a series of phases and stage-based activities, each with a particular set of tasks, associated skills and roles. Generally, the innovation process models include two common phases that each involve numerous and varying sub-stages. The first or front-end phase, described as initiationor a combination of initiation and developmental(Van de Ven et al, 1999) commonly involves generating ideas and the second or implementationphase typically involves taking action to implement them. At the human level, both phases require an individual to combine and recombine existing knowledge in new ways. Individuals participating in both phases require innovation-related competencies to be able to move between domain specific knowledge (individual's learned knowledge) and context specific knowledge (situated knowledge). From an innovation management perspective, identifying the common phases of the innovation process provides a normative condition for organizational innovation - a condition where individuals can actively engage in communication and empathetic social behavior expected with each phase's goal (Geser, 2012). This paper aims to propose a normative framework based on recurring patterns and models from prevailing innovation process studies.

\subsection{Describing and representing how innovation happens}

Generally, the innovation process literature spans linear, non-linear and cyclical phase-based 
models. A table describing historical innovation process models is provided at the end of this section (Table 2). The majority of models share key elements of ideas, implementation and evaluation. The innovation process commonly involves change in technology, human perception and affiliated social systems. Although Van de Ven and Rogers (1998:638) argue that a satisfactory model must move away from a linear, stage or phase-based process, to a dynamic, continuous conception of change over time, the literature reviewed for this article suggests there are norms - or a basic recipe.

Notable innovation process models include: Wilkening's (1953) four-stage model; Utterback and Abernathy dynamic product to process innovation models $(1975,1978)$; Roberts and Fusfeld's five (1981) critical functions model; Faste's (1987) design thinking model; Kline and Rosenberg's (1986) chain-linked model; Cooper's (1990) stage-gate model; Trice and Beyer's (1991) nineelement cultural innovation model; Rothwell's (1994) fifth-generation process model; Freeman's (1996) firm-specific linear models; Brown's (1999) six-phase design innovation model; Van de Ven et al's (1999) twelve-stage chaotic model; Tidd and Bessant's four-actions model (2001); UK Design Council's (2005) double-diamond model; Kumar's (2013) seven-modes design model; and, Rogers' (1962-2003) innovation development and diffusion of innovation models.

The first visual model of the innovation process is attributed to rural sociologist, Eugene Wilkening (1953). Wilkening describes the innovation process as a proposal of a new practice (new farming technology) that requires acceptance and approval before adoption. Wilkening's process of acceptance before adoption reflects a decision-making process, through which learning, decision and action occur over a period of time. He offers a four stage process that includes: (1) initial knowledge; (2) acceptance of practice as a good idea; (3) acceptance of the practice as trial; and, (4) adoption of the practice (Wilkening, 1953:9). Wilkening's model is significant in that it provided a theoretical and visual learning model of the innovation process. The model (Figure 1.1) offered a structured analytic and investigation process into an adoption of innovation, complete with data collecting steps. It also proposed a simple, four-phase process for future innovation studies to build upon (Godin, 2015:40).

Wilkening's visual model is introduced and discussed in the seminal work of the most attributed innovation scholar, sociologist Everett Rogers. Rogers' (1962) Rogers' introduced his Diffusion of Innovationstheory to unpack the complex innovation process. Rogers argued the innovation process consists "of all of the decisions, activities, and their impacts that occur from recognition of a need or problem, through research, development, and commercialization of an innovation, through diffusion and adoption of the innovation by users, to its consequences" (Rogers, 1995:132).

Observing the innovation process would be locus of Rogers' work for over 50 years, earning him recognition as the most influential and cited innovation scholar of the $20^{\text {th }}$ century. For innovation management researchers, it is important to acknowledge Rogers contribution to studying the innovation process. As an interdisciplinarian, he integrated Tarde's sociological Law of Imitation (1903) with aspects of economist Schumpeter's (1934) creative destruction ideologies and theories. Over his academic career he published over 3,000 works, and has been cited over 82,000 times (as of February 2018). 
Table 1.

\section{Eugene Wilkening's Process of Innovation}

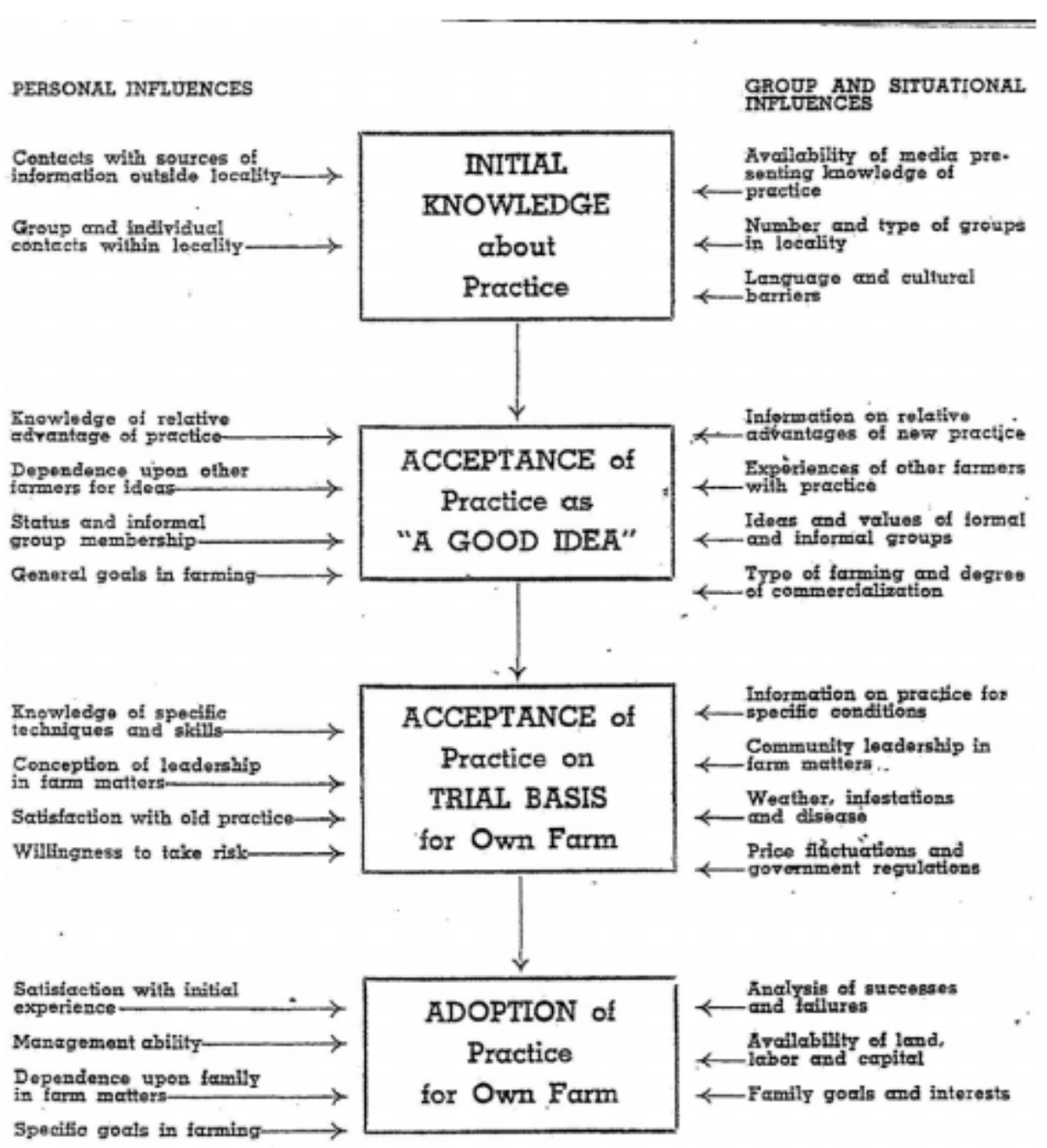

Fig. 1.-Tbi Process of Acceptance of New Farm Practices and Factors Influencing that Process.

Fig. 1. Wilkening, E. A. (1953), Adoption of Improved Farm Practices As Related to Family Factors, AES Research Bulletin no. 183, University of Wisconsin, Madison.

In contrast to his contemporaries, Rogers' work was written from a sociological, not technological perspective, focusing on the human factors and systemic conditions that affect the process, and adoption of the process, new products or new technologies. Most importantly, Rogers' research remains valuable as it offers the most detailed examination of the innovation process from both an individual and organizational perspective. Based on the initial innovation process literature reviewed and recurring descriptive patterns from multidisciplinary scholars, it appears Rogers' 
innovation-development theory (Rogers 1962-2010) may offer a normative framework for the innovation process phases and stages. The next section explores his theory in more depth.

\subsection{A systematic review of innovation process models}

This article revisits Rogers' empirically-based models, as the foundational framework from which key individual competencies associated with the innovation process can be identified and classified. Rogers (1962) first described the innovation process inside organizations as consisting of five stages that move from an initiation phase to an implementation phase, with a critical decision gate of proceeding with or aborting the process. The two phases comprise initiation and implementation, which are further described across five stages or sub-phases, being (1) agenda-setting, (2) matching, (3) redefining/restructuring, (4) clarifying, and (5) routinizing. This model reflects the most common managerial patterns of behaviour in relation to an internal innovation process (Figure 2).

\section{ROGERS' FIVE STAGES OF THE INNOVATION PROCESS IN ORGANIZATIONS}

\begin{tabular}{|c|c|c|c|c|c|}
\hline \multicolumn{6}{|c|}{ DECISION } \\
\hline 1. AGENDA-SETTING & 2. MATCHING & 3. REDEFINING/RESTRUC & ETURING & 4. CLARIFYING & 5. ROUTINIZING \\
\hline
\end{tabular}

Fig. 2. Adaptation of E. Rogers' five stages of the innovation process inside organizations

Rogers (1962-1995) also proposed a six-phase innovation-development process (Figure 3) informed by over 500 'tracer' and 'diffusion' published studies. His innovation-development theoryconsists of the recognition of a (1) need or problem and the decisions and activities involving (2) research, (3) development and (4) commercialization, (5) diffusion, and (6) consequences of an innovation's adoption by users. He suggested the phases of innovation-development are fairly accurate, however the six stages or sub-phases are not always in the same order or may not even encompass all activities of an innovation process. Rogers makes a clear request for more research to validate and evolve his well-studied model (Rogers, 1995:133). 


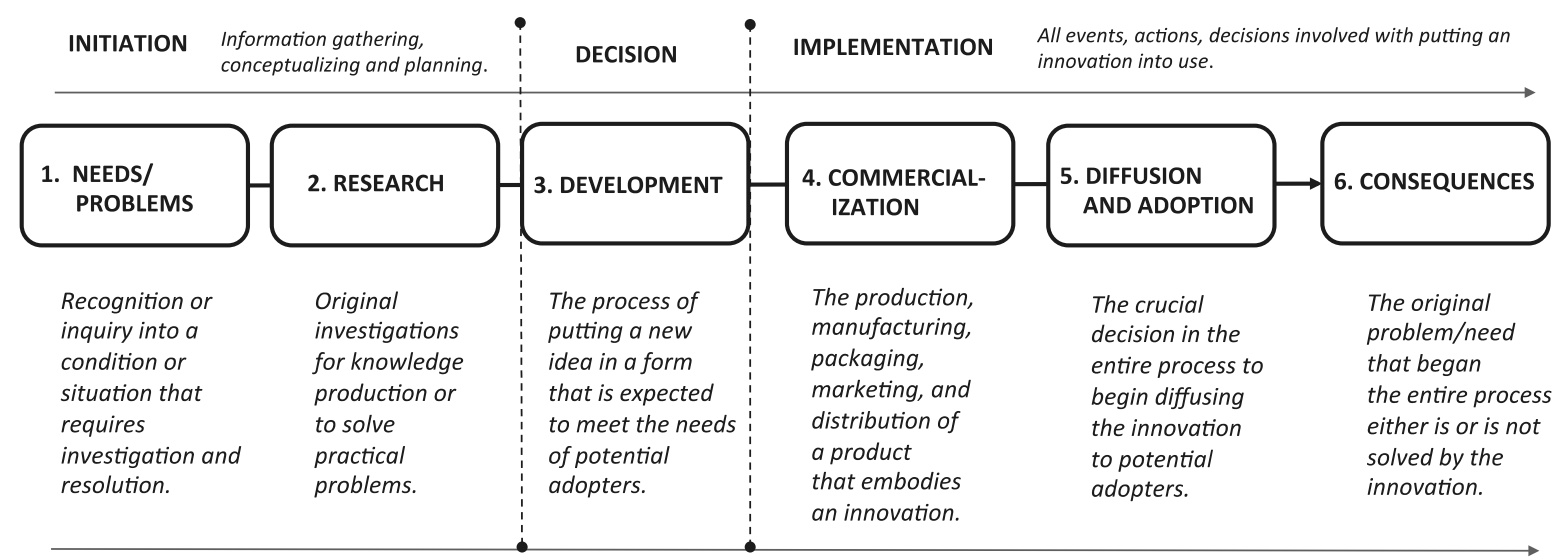

Adapted from: Rogers Everett, M. (1995). Diffusion of innovations. New York. pp:133

Fig. 3. Adaptation of E. Rogers' six stages of the innovation development process

Although Rogers argues these phases reflect a normative process, he does add that "The six phases described here may not always occur in a linear sequence, the time-order of the phases may be different, or certain phases may not occur at all" (Rogers, 1993:162). He suggests that research activities are most often how the initiation phase begins, and that the most crucial phase of decision-making is knowing if, howand whento begin diffusing an innovation to potential adopters. This prioritizing for the diffusion phase over the earlier phases is evident in most innovation process models.

Rogers' stipulates that his innovation-development process theory is concerned with whereinnovations come from, and howtheir origins cast a later influence on their diffusion and consequences. He then asserts that the pre-diffusion activities and decisions are equally important to the innovationdevelopment process, of which the diffusion phase is one component. When mapping the models across the key phases, it is evident what the locus of the models are on producing, solving and diffusion the innovation. The typology (Table 2) also makes visible the lack of research-focused activities, the steps required to understand what happens prior to the beginning of an innovation's diffusion. "This serious deficiency in previous diffusion investigations should be overcome" (Rogers, 1993:135).

Other descriptive innovation process models that reflect Rogers' research include: Van de Ven's innovation journey (1995); Freeman's (1974) systems of innovation; Duncan's (1976) ambidexturous organizations of innovation; Tidd and Besant's (2001) four action model; and Chesbrough's open innovation model (2003). These models, along with other notable innovation process models, reflect the two common phases consistent with Rogers' two-phased model of initiation (research focused) and implementation (solution focused). The table below (Table 2) provides a detailed classification of multidisciplinary innovation process models grouped into researchfocused (problem) or solution-focused phases, stages and activities. 
Table 2. Classification of innovation process models mapped across two key phases

\begin{tabular}{|c|c|c|}
\hline Author & $\begin{array}{l}\text { Initiation Phase } \\
\text { (Research) }\end{array}$ & Implementation Phase (Solution) \\
\hline Wilkening (1953) & $\begin{array}{l}\text { 1. Initial knowledge about } \\
\text { the practice }\end{array}$ & $\begin{array}{l}\text { 2. Acceptance of the practice as "a Good } \\
\text { Idea" } \\
\text { 3. Acceptance of the practice on Trial } \\
\text { Basis } \\
\text { 4. Adoption of the practice }\end{array}$ \\
\hline Maclaurin (1953) & $\begin{array}{l}\text { 1. Pure Science } \\
\text { 2. Invention }\end{array}$ & $\begin{array}{l}\text { 3. Innovation } \\
\text { 4. Finance } \\
\text { 5. Acceptance or Diffusion }\end{array}$ \\
\hline Ruttan (1959) & 1. Invention & $\begin{array}{l}\text { 2. Innovation } \\
\text { 3. Technological Change }\end{array}$ \\
\hline $\begin{array}{l}\text { Rogers (1962-1999) } \\
\text { Innovation } \\
\text { Development Process } \\
\text { Theory }\end{array}$ & $\begin{array}{l}\text { 1. Needs/Problem } \\
\text { Recognition } \\
\text { 2. Research }\end{array}$ & $\begin{array}{l}\text { 3. Development } \\
\text { 4. Commercialization } \\
\text { 5. Diffusion and Adoption } \\
\text { 6. Consequences }\end{array}$ \\
\hline $\begin{array}{l}\text { Simon (1969) Theory of } \\
\text { Design }\end{array}$ & $\begin{array}{l}\text { 1. Intelligence Gathering } \\
\text { (environment) }\end{array}$ & $\begin{array}{l}\text { 2. Design (invention and development) } \\
\text { 3. Choice (direction of course) }\end{array}$ \\
\hline $\begin{array}{l}\text { Rogers (1962-1999) } \\
\text { Organizational } \\
\text { Innovation Theory }\end{array}$ & $\begin{array}{l}\text { Stage 1: Agenda-Setting } \\
\text { Stage 2: Matching }\end{array}$ & $\begin{array}{l}\text { Stage 3: Redefining/restructuring } \\
\text { Stage 4: Clarifying } \\
\text { Stage 5: Routinizing }\end{array}$ \\
\hline $\begin{array}{l}\text { Argyris and Schön } \\
\text { 1978) }\end{array}$ & Double Loop: Problem & $\begin{array}{l}\text { Double Loop: Solution } \\
\text { Double Loop: Implementation }\end{array}$ \\
\hline $\begin{array}{l}\text { Roberts and Fusfeld } \\
\text { (1981) }\end{array}$ & Stage 1: Idea generation & $\begin{array}{l}\text { Stage 2: Championing } \\
\text { Stage 3: Project leading } \\
\text { Stage 4: Gatekeeping } \\
\text { Stage 5: Project sponsoring or coaching }\end{array}$ \\
\hline $\begin{array}{l}\text { Kline and Rosenberg } \\
(1986)\end{array}$ & $\begin{array}{l}\text { 1. Potential Market } \\
\text { 2. Invention/Analytic } \\
\text { Design }\end{array}$ & $\begin{array}{l}\text { 3. Detailed Design and Test } \\
\text { 4. Redesign and Produce } \\
\text { 5. Distribute and Market }\end{array}$ \\
\hline Cooper (1990) & $\begin{array}{l}\text { Stage } 0 \text { - Discovery: Ideas } \\
\text { Stage } 1 \text { - Scoping: } \\
\text { Assessment }\end{array}$ & $\begin{array}{l}\text { Stage } 2 \text { - Build Business Case: New } \\
\text { product } \\
\text { Stage } 3 \text { - Development: Development } \\
\text { Stage } 4 \text { - Testing and Validation: } \\
\text { Stage } 5 \text { - Launch: Commercialization }\end{array}$ \\
\hline Kelley (1991) & $\begin{array}{l}\text { 1. Empathize } \\
\text { 2. Define }\end{array}$ & $\begin{array}{l}\text { 3. Ideate } \\
\text { 4. Prototype } \\
\text { 5. Test }\end{array}$ \\
\hline Buchanan (1992) & $\begin{array}{l}\text { 1. Problem definition } \\
\text { (analytic step) }\end{array}$ & $\begin{array}{l}\text { 2. Problem solution (synthetic sequence } \\
\text { step) }\end{array}$ \\
\hline
\end{tabular}




\begin{tabular}{|c|c|c|}
\hline Author & $\begin{array}{l}\text { Initiation Phase } \\
\text { (Research) }\end{array}$ & Implementation Phase (Solution) \\
\hline $\begin{array}{l}\text { Ulrich and Eppinger } \\
(1995)\end{array}$ & $\begin{array}{l}\text { Phase 1: Concept } \\
\text { Development }\end{array}$ & $\begin{array}{l}\text { Phase 2: System-Level Design } \\
\text { Phase 3: Detail Design } \\
\text { Phase 4: Testing and Refinement } \\
\text { Phase 5: Production Ramp-Up }\end{array}$ \\
\hline Freeman (1996) & 1. Basic Research & $\begin{array}{l}\text { 2. Applied Research } \\
\text { 3. Invention } \\
\text { 4. Marketing Testing } \\
\text { 5. Diffusion and Imitation }\end{array}$ \\
\hline Faste (1998) & 1. Express (idea generation) & $\begin{array}{l}\text { 2. Test (prototyping and design) } \\
\text { 3. Cycle (solution modification and } \\
\text { development) }\end{array}$ \\
\hline Brown (1999) & 1. Observation & $\begin{array}{l}\text { 2. Ideation } \\
\text { 3. Rapid Prototyping } \\
\text { 4. User Feedback } \\
\text { 5. Iteration } \\
\text { 6. Implementation } \\
\end{array}$ \\
\hline $\begin{array}{l}\text { Van de Ven, Polley, } \\
\text { Garud and } \\
\text { Venkataraman (1999) }\end{array}$ & $\begin{array}{l}\text { 1. Gestation } \\
\text { 2. Shock }\end{array}$ & $\begin{array}{l}\text { 3. Plans } \\
\text { 4. Proliferation } \\
\text { 5. Setbacks } \\
\text { 6. Criteria Shift } \\
\text { 7. Fluid participation of organizational } \\
\text { personnel } \\
\text { 8. Investor/top management } \\
\text { 9. Relationship with others } \\
\text { 10. Infrastructure develop } \\
\text { 11. Adoption } \\
\text { 12. Termination }\end{array}$ \\
\hline $\begin{array}{l}\text { Tidd and Bessant } \\
\text { (1998) }\end{array}$ & 1. Search (for opportunities) & $\begin{array}{l}\text { 2. Select (key opportunity) } \\
\text { 3. Implement (innovation) } \\
\text { 4. Capture (manage and measure) }\end{array}$ \\
\hline $\begin{array}{l}\text { UK Design Council } \\
(2005)\end{array}$ & $\begin{array}{l}\text { 1. Discover } \\
\text { 2. Define }\end{array}$ & $\begin{array}{l}\text { 3. Develop } \\
\text { 4. Deliver }\end{array}$ \\
\hline Brown (2009) & $\begin{array}{l}\text { 1. Inspiration - the problem } \\
\text { or opportunity that } \\
\text { motivates the search for } \\
\text { solutions; }\end{array}$ & $\begin{array}{l}\text { 2. Ideation - the process of generating, } \\
\text { developing and testing ideas; and, } \\
\text { 3. Implementation - the path that leads } \\
\text { from the design studio, lab and factory to } \\
\text { the market. }\end{array}$ \\
\hline Quayle (2009) & $\begin{array}{l}\text { Ask: finding problems and } \\
\text { needs }\end{array}$ & $\begin{array}{l}\text { Try: prototype and test ideas } \\
\text { Do: make decisions, build ideas }\end{array}$ \\
\hline Kumar (2013) & $\begin{array}{l}\text { Mode 1: Sense Intent } \\
\text { Mode 2: Know Context } \\
\text { Mode 3: Know People }\end{array}$ & $\begin{array}{l}\text { Mode 4: Frame Insights } \\
\text { Mode 5: Explore Concepts } \\
\text { Mode 6: Frame Solutions } \\
\text { Mode 7: Realize Offering }\end{array}$ \\
\hline
\end{tabular}


When collecting the description of the innovation process phases from diverse authors, a lack of shared vocabulary is surfaced. However, when interpreting the diverse process models into core innovation process elements comprised of inputs and outputs (Du Chatelier, 2009), they do reflect the common goals of Rogers' initiation and implementation phases.

When classifying the innovation process models across the two key phases, it is evident that the initiation, or research-focused phase, involves relatively fewer activities when compared with the implementation or solution-focused phase. This typological framework infers degrees of simplicity to complexity with the innovation process phases. There are relatively few activities associated with the initiation phase, and significantly more activities and possibly more complexity associated with the implementation phase of the innovation process. The oversimplification of the initiation phase, or front end of the innovation process, should raise concern on how researching the needs or problems can be completed through so few activities.

I interpret this imbalance of activities as a reflection of placing higher value on the implementation or solution phase, and less on the initiation, research or problem-finding phase. This finding reflects the capital investments commonly made on the later phase, and the systematic approach to diffuse and commercialize an innovation. It might also suggest why the majority of organizational leaders are challenged to engage in the exploratory early phase of the innovation process - as the activities and outputs are less defined, and potentially perceived of lesser value. Perhaps it is not surprising that management education has placed greater emphasis on providing knowledge and tools for the implementation phase of the innovation process. Considering the innovation process requires the effective management of numerous activities and associated risk with diffusing a new idea (or innovation) to the market, the focus on the implementation phase is important. This finding may be of value for future studies.

Notably, what this classification table does reveal is the need for innovation management educators to engage learners in the effective participation and leadership of the entire innovation process, paying particular attention to the initiation phase. This topic however is a discussion for another paper. This paper is concerned with deconstructing the innovation process through descriptive models, revisiting a well- studied innovation process (e.g. Roger's innovationdevelopment process) to identify recurring process patterns, and key competencies necessary for understanding and individual practice with the innovation process.

\section{Mapping innovative competencies across a normative framework}

This section offers an initial classification of competencies affiliated with the innovation process. The proposed normative framework is Rogers' innovation-development process comprised of six key phases. The framework provides a construct to explore and identify key individual innovative competencies associated with critical actions and decisions made along the innovation process journey. Innovation-related competencies are generally described as knowledge-based capabilities, aptitudes and skills integrated within organizational innovation management activities and systems (Leonard-Barton, 1995; Schmitt \& Chan, 1998). Competence and competency generally denote a person's ability to understand or perform a certain task. 
The concept of 'core competence' was first introduced by Prahalad and Hamel (1990). They defined it as the integration of the skills, techniques, specialty knowledge, experience and technology an organization possesses. They argued that core competence is the engine for effective product and service innovation. Pavitt (1991) then asserted that organizations could gain innovative advantage through building up their competencies, which are costly and difficult for competitors to imitate. Leonard-Barton (1992) offered four dimensions of innovation-related core competencies. They included: (1) employee knowledge and skills (2) embedded into technical systems; the process of knowledge creation and control are guided by (3) managerial systems; and, (4) the values and norms associated with various types of embodied and embedded knowledge and knowledge creation processes. (113). Tidd (2000) adapted Leonard-Barton's classification to "market competencies", grouping people's knowledge, managerial systems and norms together in a broader dimension to cover the organization's ability to understand and develop markets.

More recently, authors including Du Chatenier (2009), Bartram (2005), and West et al. (2006), have begun investigating individual factors and qualities associated with 'open innovation competence'. Du Chatenier suggests an emerging concept for innovation-related competence is the work-oriented approach introduced by Delamare Le Deist \& Winterton (2005). Their approach emphasizes job-related functional skills, contextual knowledge, and related work-tasks. Competence is measured by predetermined performance metrics (Du Chatenier, 2005:20).

The competencies identified and explored in this paper focus on the individual within an organization, and are mapped onto Rogers' innovation development process (IDP) phases (Table 3). The proposed competency typology is adapted from van Dam et al's (2010) model developed from their teaching entrepreneurial behaviour studied. It also reflects Du Chatenier's model for open innovation competence (2005:22), however maps innovative competencies to the proposed normative framework of Rogers' IDP and not open innovation models. It comprises three categories of innovativeness competencies: knowledge, aptitudes and skills. Knowledge refers to the information, understanding, or skill that one develops from experience or education (Merriam-Webster, 2016). For this framework, knowledgeis concerned with topics relevant to the innovation process and the context, along with the ability to successfully integrate it into specific task-related behaviour (Hayton and Kelley, 2006; Nordhaug and Gronhaug, 1994). Aptituderefers to the ability to do something or to learn something (Merriam-Webster, 2016), however they can be discovered following the exposure or experience with a specific situation. Skillrefers to the ability to use one's knowledge effectively and readily in execution or performance (Merriam-Webster, 2016).

The competence framework below (Table 3) proposes a typology of the individual's knowledge, aptitudes and skills associated with Rogers' six-phase innovation development process (IDP). The types of knowledgeidentified, include: domain and procedural knowledge; inquiry methods; design knowledge; production; market knowledge; innovation management; technical knowledge; and, reflective practice knowledge. The aptitudesidentified include: empathy, need and problem finding; qualitative and quantitative research and systems thinking; prototyping and design thinking; operations management and marketing; decision-making; data analysis; evaluation; and, mixed methods research. The skillsidentified include: creative and critical thinking; problem identification and visual thinking; collaboration and decision-making; project management and package design; business analysis, reflective thinking; and, communication. 
Table 3. Proposed innovative competencies framework based on Rogers' IDP

\begin{tabular}{|c|c|c|c|}
\hline \multirow{2}{*}{$\begin{array}{l}\text { Rogers' IDP } \\
\text { phases }\end{array}$} & \multicolumn{3}{|c|}{ Proposed Innovative Competencies Framework } \\
\hline & Knowledge & Aptitudes & Skills \\
\hline $\begin{array}{l}\text { 1. Needs/ } \\
\text { Problems: } \\
\text { Recognition or } \\
\text { inquiry into a } \\
\text { condition or } \\
\text { situation that } \\
\text { requires } \\
\text { investigation and } \\
\text { resolution. }\end{array}$ & $\begin{array}{l}\text { - Domain } \\
\text { knowledge: } \\
\text { Content and } \\
\text { information } \\
\text { processing } \\
\text { knowledge required } \\
\text { for the task or } \\
\text { situated challenge } \\
\text { (Glynn, 1996). } \\
\text { - Procedural } \\
\text { knowledge: } \\
\text { Process-based } \\
\text { knowledge required } \\
\text { for the acquisition } \\
\text { and analysis of new } \\
\text { information; or to } \\
\text { combine existing } \\
\text { information in new } \\
\text { ways. (Glynn, } \\
\text { 1996; Steinberg, } \\
\text { 1985). }\end{array}$ & $\begin{array}{l}\text { - Needs finding: a need is } \\
\text { best described as a } \\
\text { perceived lack, or } \\
\text { something that is missing } \\
\text { (Faste, } 1987 \text { and Maslow, } \\
\text { 1943). Needs finding } \\
\text { requires empathy. } \\
\text { - Empathy: involves ones } \\
\text { reactions and recognitions } \\
\text { of these reactions to the } \\
\text { observed experiences of } \\
\text { others (Davis, 1994) } \\
\text { - Problem finding: is a } \\
\text { process of inquiry that } \\
\text { involves scanning the } \\
\text { environment to find and } \\
\text { define the problem in such } \\
\text { a way that it can be solved. }\end{array}$ & $\begin{array}{l}\text { - Creative thinking: the } \\
\text { ability to think } \\
\text { imaginatively and } \\
\text { deliberately in ways to } \\
\text { approach problems. } \\
\text { - Critical thinking: the } \\
\text { ability to think clearly and } \\
\text { rationally, understanding } \\
\text { the logical connection } \\
\text { between ideas; to engage in } \\
\text { reflective and independent } \\
\text { thought. } \\
\text { - Communication: the } \\
\text { ability to listen and speak } \\
\text { effectively, present ideas } \\
\text { appropriately, and write } \\
\text { clearly and concisely. }\end{array}$ \\
\hline
\end{tabular}




\begin{tabular}{|c|c|c|c|}
\hline \multirow{2}{*}{$\begin{array}{l}\text { Rogers' IDP } \\
\text { phases }\end{array}$} & \multicolumn{3}{|c|}{ Proposed Innovative Competencies Framework } \\
\hline & Knowledge & Aptitudes & Skills \\
\hline $\begin{array}{l}\text { 2. Research: } \\
\text { Original } \\
\text { investigations for } \\
\text { knowledge } \\
\text { production or to } \\
\text { solve practical } \\
\text { problems. }\end{array}$ & $\begin{array}{l}\text { - Inquiry Methods: } \\
\text { Ways to develop } \\
\text { information } \\
\text { processing and } \\
\text { problem-solving } \\
\text { skills. Involves } \\
\text { identifying the } \\
\text { problem or which } \\
\text { resources are } \\
\text { needed to better } \\
\text { understand the } \\
\text { problem; } \\
\text { evaluating the } \\
\text { gathered } \\
\text { information, and } \\
\text { using it effectively } \\
\text { to address or solve } \\
\text { the problem. }\end{array}$ & $\begin{array}{l}\text { - Qualitative research: the } \\
\text { ability to collect and } \\
\text { manage unstructured and } \\
\text { field note data, think } \\
\text { analytically and synthesize } \\
\text { information into reportable } \\
\text { and understandable } \\
\text { formats. } \\
\text { - Quantitative research: } \\
\text { the ability to collect, } \\
\text { manage and analyze } \\
\text { structured data into } \\
\text { quantifiable terms. } \\
\text { - Systems thinking: the } \\
\text { ability to understand how } \\
\text { concepts regarded as } \\
\text { systems work and how they } \\
\text { influence one another } \\
\text { within a larger system. } \\
\text { - Decision-making: the } \\
\text { ability to make a critical } \\
\text { decision to begin the } \\
\text { development process of the } \\
\text { innovation to potential } \\
\text { adopters. }\end{array}$ & $\begin{array}{l}\text { - Problem identification: } \\
\text { involves identifying and } \\
\text { effectively communicating } \\
\text { the problem statement. } \\
\text { - Visual thinking: the } \\
\text { ability to model and } \\
\text { visualize concepts before all } \\
\text { the information is available. } \\
\text { - Creative thinking: (see } \\
\text { above) } \\
\text { - Critical thinking: (see } \\
\text { above) } \\
\text { - Collaboration: the ability } \\
\text { to participate in group } \\
\text { tasks, and facilitate } \\
\text { effective group-based work. } \\
\text { - Communication: the } \\
\text { ability to listen and speak } \\
\text { effectively, present ideas } \\
\text { appropriately, and write } \\
\text { clearly and concisely. }\end{array}$ \\
\hline $\begin{array}{l}\text { 3. Development: } \\
\text { The process of } \\
\text { putting a new } \\
\text { idea in a form } \\
\text { that is expected } \\
\text { to meet the needs } \\
\text { of potential } \\
\text { adopters. }\end{array}$ & $\begin{array}{l}\text { - Design Methods: } \\
\text { Ways of putting a } \\
\text { new idea in a form } \\
\text { that is expected to } \\
\text { meet the needs of } \\
\text { an audience of } \\
\text { potential adopters. }\end{array}$ & $\begin{array}{l}\text { - Prototyping: the ability } \\
\text { to generate concrete } \\
\text { samples or models for the } \\
\text { purpose of testing the } \\
\text { concept or process to learn } \\
\text { and then replicate from. } \\
\text { - Design thinking: the } \\
\text { ability to work at varying } \\
\text { levels of abstraction; to } \\
\text { recognize a broad range of } \\
\text { potential solutions from a } \\
\text { given problem statement. } \\
\text { - Decision-making: the } \\
\text { ability to make a critical } \\
\text { decision to begin the } \\
\text { development process of the } \\
\text { innovation to potential } \\
\text { adopters. }\end{array}$ & $\begin{array}{l}\text { - Collaboration: (see } \\
\text { above) } \\
\text { - Decision-making: the } \\
\text { ability to choose between } \\
\text { two or more alternatives or } \\
\text { courses of action; engage in } \\
\text { an intuitive and reasoned } \\
\text { process. } \\
\text { - Design thinking: the } \\
\text { ability to to recognize a } \\
\text { broad range of potential } \\
\text { solutions from a given } \\
\text { problem statement. } \\
\text { - Communication: the } \\
\text { ability to listen and speak } \\
\text { effectively, present ideas } \\
\text { appropriately, and write } \\
\text { clearly and concisely. }\end{array}$ \\
\hline
\end{tabular}




\begin{tabular}{|c|c|c|c|}
\hline \multirow{2}{*}{$\begin{array}{l}\text { Rogers' IDP } \\
\text { phases }\end{array}$} & \multicolumn{3}{|c|}{ Proposed Innovative Competencies Framework } \\
\hline & Knowledge & Aptitudes & Skills \\
\hline $\begin{array}{l}\text { 4. Commerciali- } \\
\text { zation: The } \\
\text { production, } \\
\text { manufacturing, } \\
\text { packaging, } \\
\text { marketing, and } \\
\text { distribution of an } \\
\text { innovation. }\end{array}$ & $\begin{array}{l}\text { - Production } \\
\text { Methods: } \\
\text { Engineering and } \\
\text { operations } \\
\text { management } \\
\text { knowledge to } \\
\text { create and } \\
\text { fabricate } \\
\text { innovation. } \\
\text { - Design Methods: } \\
\text { (see above) } \\
\text { - Market } \\
\text { Intelligence: } \\
\text { Supply chain and } \\
\text { market } \\
\text { development } \\
\text { knowledge to } \\
\text { identify } \\
\text { production, } \\
\text { manufacturing, } \\
\text { marketing, and } \\
\text { distribution } \\
\text { partners. }\end{array}$ & $\begin{array}{l}\text { - Operations management: } \\
\text { the ability to understand } \\
\text { the process and functions } \\
\text { relating to the } \\
\text { manufacturing, packaging } \\
\text { and delivery or distribution } \\
\text { of the innovation. } \\
\text { - Market research: the } \\
\text { ability to plan, design and } \\
\text { implement market } \\
\text { development strategies; to } \\
\text { apply knowledge of the } \\
\text { principles and tools of } \\
\text { R\&D to solving problems } \\
\text { relating to the consumer, } \\
\text { user or market. } \\
\text { - Decision-making: (see } \\
\text { above) }\end{array}$ & $\begin{array}{l}\text { - Project management: the } \\
\text { ability to understand and } \\
\text { navigate a project initiation } \\
\text { through to completion; to } \\
\text { communicate and manage } \\
\text { phases and outcomes with } \\
\text { teams and leaders. } \\
\text { - Design thinking: (see } \\
\text { above). } \\
\text { - Package design: the } \\
\text { ability to create an } \\
\text { aesthetic form or design for } \\
\text { the innovation. } \\
\text { - Creative thinking: (see } \\
\text { above) } \\
\text { - Critical thinking: (see } \\
\text { above) } \\
\text { - Communication: (see } \\
\text { above) }\end{array}$ \\
\hline $\begin{array}{l}\text { 5. Diffusion and } \\
\text { adoption: The } \\
\text { crucial decision } \\
\text { in the entire } \\
\text { process to begin } \\
\text { diffusing the } \\
\text { innovationto } \\
\text { potential } \\
\text { adopters. }\end{array}$ & $\begin{array}{l}\text { - Market } \\
\text { Intelligence: See } \\
\text { above. } \\
\text { - Innovation } \\
\text { management: } \\
\text { Knowledge of } \\
\text { product and } \\
\text { organizational in- } \\
\text { novation processes, } \\
\text { tools and } \\
\text { measures. }\end{array}$ & $\begin{array}{l}\text { - Marketing: the ability to } \\
\text { plan, design and implement } \\
\text { market development and } \\
\text { communication strategies; } \\
\text { to apply knowledge from } \\
\text { the R\&D and production } \\
\text { process and communicate } \\
\text { to the target adopting } \\
\text { market. } \\
\text { - Decision-making: (see } \\
\text { above) }\end{array}$ & $\begin{array}{l}\text { - Project management: } \\
\text { (see above) } \\
\text { - Creative thinking: (see } \\
\text { above) } \\
\text { - Critical thinking: (see } \\
\text { above) } \\
\text { - Communication: (see } \\
\text { above) }\end{array}$ \\
\hline
\end{tabular}




\begin{tabular}{|c|c|c|c|}
\hline \multirow{2}{*}{$\begin{array}{l}\text { Rogers' IDP } \\
\text { phases }\end{array}$} & \multicolumn{3}{|c|}{ Proposed Innovative Competencies Framework } \\
\hline & Knowledge & Aptitudes & Skills \\
\hline $\begin{array}{l}\text { 6. Consequences: } \\
\text { The original } \\
\text { problem/need } \\
\text { that beganthe } \\
\text { entire process } \\
\text { either is or is not } \\
\text { solved by the } \\
\text { innovation. }\end{array}$ & $\begin{array}{l}\text {-Innovation } \\
\text { management: (see } \\
\text { above) } \\
\text { - Reflective } \\
\text { practice: Ways to } \\
\text { reflect on processes } \\
\text { and actions to } \\
\text { ensure continuous } \\
\text { learning. Methods } \\
\text { of examining and } \\
\text { evaluating } \\
\text { standards and } \\
\text { consequences } \\
\text { (King, 2005). }\end{array}$ & $\begin{array}{l}\text { - Data analysis: the ability } \\
\text { to assess the validity, } \\
\text { reliability and } \\
\text { trustworthiness of data; } \\
\text { and, analyze and interpret } \\
\text { the data. } \\
\text { - Evaluation: the ability to } \\
\text { frame evaluation questions, } \\
\text { determine criteria, and } \\
\text { define evaluation methods } \\
\text { (quantitative, qualitative or } \\
\text { mixed). } \\
\text { - Decision-making: (see } \\
\text { above) }\end{array}$ & $\begin{array}{l}\text { - Business analysis: the } \\
\text { ability to review and } \\
\text { critically evaluate the } \\
\text { process, output and impact } \\
\text { of the innovation; to create } \\
\text { clear and concise } \\
\text { documentation. } \\
\text { - Critical thinking: (see } \\
\text { above) } \\
\text { - Reflective thinking: the } \\
\text { ability to relate new } \\
\text { knowledge to prior } \\
\text { understanding; and, to } \\
\text { think in abstract and } \\
\text { concrete terms. } \\
\text { - Communication: (see } \\
\text { above) }\end{array}$ \\
\hline
\end{tabular}

The aptitudes and skills that repeat across multiple phases in this proposed framework include: decision-making; communication; creative and critical thinking; design thinking; collaboration; and, project management. These competencies reflect the innovation process literature, and in particular, Rogers' (1993) description of the innovation process 'as a communication process'. I agree with Rogers and his contemporaries that organizational innovation is a communication process. As such, organizations must rely on the capability of their individual members to think, act and produce (Geser, 2014) in innovative ways. To do so effectively, requires individual members to develop an awareness, understanding and literacy of innovation.

The normative framework for the innovation development process, and the associated competencies suggest what Rogers' refers to as 'ideal types'. "Ideal types are conceptualizations based on observations of reality and designed to make comparisons possible. The function of ideal types is to guide research efforts and to serve as a framework for the synthesis of research findings" (Rogers, 1983; 247). "Ideal types are based on abstractions from empirical cases and are intended as a guide for theoretical formulations and empirical investigations" (Rogers, 1983:248).

I propose that understanding the individual competencies required to effectively participate and ultimately manage the innovation process is critical for organizations seeking to survive, grow and prosper. I also suggest that management schools consider designing their innovation pedagogy with a normative framework as a construct from which to map and discuss associated innovative competencies. 


\section{Discussion and Conclusions}

This paper examined how the innovation process happens and how innovative capacity or innovative competence may be developed. The innovation process is a sequence of activities involving an intention to solve a problem specific to a particular context, the development of something perceived as new, and the adoption of the new element, over a period of time (Beausoleil, 2016)

In his seminal work, the Diffusion of Innovations (1962-2010), Rogers provides a detailed translation of the innovation process from thousands of research studies, as both experienced and recalled by its participants. His research would produce over 12 theoretical models and frameworks introduced in its first edition. Although readers would focus on his overarching diffusion of innovations theory as a predictor of an innovation's adoption by an individual or organization, it is his innovation-development process (IDP) that is the locus of this article. Rogers IDP model represented how firms initiated, organized and made decisions around ideas and innovation, prior to any diffusion or adoption.

Many studies have examined entrepreneurial and intrapreneurial traits and training methods. However, only a few have investigated a pedagogy and associated competencies required for individuals to explicitly and effectively engage in the process of innovation (Leonard-Barton, 1992; Midgley and Dowling, 1978; Tidd and Bessant, 2001; Matthews and Brueggemann, 2015). Considering innovation's core resource is human capital, more research is needed to first observe and analyze how humans and their social systems innovate, and then to design the appropriate academic, economic, technological and political infrastructures.

This article suggests innovation-related competencies can be identified with the aid of normative frameworks. Once mapped to empirically-researched models, we can then begin to investigate instructional interventions in the development of this competencies through action research studies on innovation management pedagogy, in business schools and through executive education programs.

The findings from the document analysis provide a categorization of innovation-process models, a normative framework for the innovation process, and a typology of competencies that suggest individual innovativeness can be developed for specific phases of the innovation process. The analysis also suggests the framework may be useful to guide the design of innovation management pedagogy and for future action research studies.

How a social system (e.g. organization) is organized for an innovation process and what individualmember competencies are required to effectively participate in that process, is the topic of this paper. Potential benefits of providing a normative framework include: for individuals, an orienteering guide through innovation's uncertain journey; for innovation managers, a decision-making framework; and, for innovation management instructors, a pedagogical construct to lead action research studies. The figure below (Fig 4) demonstrates how this framework may be diffused from the initiation and through to the implementation phases discussed in this paper. 


\begin{tabular}{|c|c|c|c|c|c|}
\hline INITIATION & $\begin{array}{l}\text { Information gathering, } \\
\text { conceptualizing and planning. }\end{array}$ & DECISION & IMPLEMENTATION & \multicolumn{2}{|c|}{$\begin{array}{l}\text { All events, actions, decisions involved with putting an } \\
\text { innovation into use. }\end{array}$} \\
\hline $\begin{array}{l}\text { 1. NEEDS/ } \\
\text { PROBLEMS }\end{array}$ & 2. RESEARCH & 3. DEVELOPMENT & $\begin{array}{l}\text { 4. COMMERCIAL- } \\
\text { IZATION }\end{array}$ & $\begin{array}{l}\text { 5. DIFFUSION } \\
\text { AND ADOPTION }\end{array}$ & 6. CONSEQUENCES \\
\hline $\begin{array}{l}\text { Inquiry into the lack } \\
\text { of innovation } \\
\text { process and } \\
\text { innovative } \\
\text { competencies } \\
\text { understanding; } \\
\text { reduce uncertainty } \\
\text { with process. }\end{array}$ & $\begin{array}{l}\text { Investigation of } \\
\text { academicand } \\
\text { industry } \\
\text { frameworks, and } \\
\text { models of } \\
\text { normative } \\
\text { innovation } \\
\text { processes. }\end{array}$ & $\begin{array}{l}\text { Prototyping and } \\
\text { proposing a } \\
\text { normative } \\
\text { framework for } \\
\text { action-research } \\
\text { study with } \\
\text { potential } \\
\text { adopters. }\end{array}$ & $\begin{array}{l}\text { Producing } \\
\text { models of the } \\
\text { normative } \\
\text { framework for } \\
\text { action research } \\
\text { studies; } \\
\text { publishing the } \\
\text { findings. }\end{array}$ & $\begin{array}{l}\text { Producing and } \\
\text { distributing a } \\
\text { normative framework } \\
\text { for classroom and } \\
\text { industry use; } \\
\text { instructional guide } \\
\text { and learning } \\
\text { materials. }\end{array}$ & $\begin{array}{l}\text { Evaluating if the } \\
\text { framework } \\
\text { increased } \\
\text { understanding } \\
\text { and reduced } \\
\text { innovation } \\
\text { process } \\
\text { uncertainty. }\end{array}$ \\
\hline
\end{tabular}

Fig. 4. Adaptation of E. Rogers' innovation development process for this normative framework.

As innovation process scholars, there is a need to consider the need for academic translation, multi and translingualism which is critical to understand past, existing and emerging innovation development processes and associated competencies. The success with the diffusion and adoption of this knowledge might be found in the interdisciplinary approach to our research.

\section{Limitations of Analysis}

Although document analysis is well practiced as a qualitative research method, it also has limitations. Although the documents reviewed in this article provide background and context, it is limited to a selection of associated theoretical and empirical studies.

For this paper, the analysis was limited in coverage and biased in selectivity and interpretation. The literature reviewed provided a broad coverage, over a long span of time and across disciplines, however it did include extensive works on organizational competencies. The analysis also presented a biased selectivity (Yin, 1994), reflecting an incomplete collection of research published by less cited authors and in areas that span human resources, organizational competencies, etc. The paper also reflects a bias toward word and phrase selection; literature explicitly discussing "innovation process" and "innovation as a process" were prioritized.

The proposed normative framework and associated innovative competencies are interpreted as 'ideal types' of knowledge, aptitude and skills (Rogers 1983; 269). Further studies are warranted on the proposed normative framework for the innovation-development process.

All copyright material submitted in this article has been authorized by the owner. 


\section{References}

Abernathy, W.J. and Utterback, J. (1978), "Patterns of industrial innovations", Technology Review, Vol. 80 No. 7, pp. 40-7.

Amabile, T.M. (1988). A model of creativity and innovation in organizations. Research in Organizational Behaviour, 10, 123167.

Amabile, T.M., \& Gryskiewicz, S.S. (1987). Creativity in the RED laboratory. Technical Report No. 30. Center for Creative Leadership

Argyris, C., \& Schön, D. A. (1978). Organizational learning: A theory of action perspective (Vol. 173). Reading, MA: Addison-Wesley.

Argyris, C., \& Schön, D. A. (1996). Organizational learning II. Addison Wesley.

Bartram, D. (2005). The great eight competencies: A criterion-centric approach to validation. Journal of Applied Psychology, 90(6), 1185-1203.

Bessant, J. (2016). Teaching and Coaching Innovation in innovative fashion! Wiley Online. Retrieved 2016-09-26 from: https://johnrbessant.files.wordpress.com/2016/03/tacit_brouchure.pdf

Bicchieri, Cristina (2005). The Grammar of Society: The Nature and Dynamics of Social Norms. Cambridge University Press.

Buchanan, R. (1992). Wicked problems in design thinking. Design Issues, 8(2), 5-21.

Bush, V. (1945). Science, the endless frontier: A report to the President. US Govt. print. off.

Brown, T., \& Katz, B. (2011). Change by design. Journal of product innovation management, 28(3), 381-383.

Damanpour F. (1991) Organizational innovation: a meta-analysis of effects of determinants, and moderators. Academy of Management Journal. 34 (3):555-90.

Davis, M. H. (1994). Empathy: A social psychological approach. Westview Press.

Dearborn, D. C., Kneznek, R. W., \& Anthony, R. N. (1953). Spending for industrial research, 1951-1952. HARVARD UNIV CAMBRIDGE MA GRADUATE SCHOOL OF BUSINESS ADMINISTRATION.

Djellal, F. \& Gallouj, F. (2014) The laws of imitation and invention: Gabriel Tarde and the evolutionary economics of innovation.

Du Chatenier, E.J. (2009), Open innovation competence: Towards a competence profile for inter-organizational collaboration innovation teams.

Faste, R. A. (1987) Perceiving Needs. SAE Journal, Society of Automotive Engineers.

Faste, R., \& Roth, B. (1998). The Design of Projects and Contests-the Rules of the Game. Journal of Robotics and Mechatronics,10, 7-13.

Fonseca, J. (2002). Complexity and innovation in organizations. Psychology Press. 
Geser, H. (2012). Towards an Interaction Theory of Organizational Actors. Institute of Sociology, University of Zürich, Switzerland

Godin, B. (2006). The linear model of innovation: The historical construction of an analytical framework. Science, Technology, \& Human Values, 31(6), 639-667.

Godin, B. (2014). Invention, diffusion and linear models of innovation: The contribution of anthropology to a conceptual framework. Journal of Innovation Economics 85 Management, n15(3), 11-37 Godin, B. (2015). Models of Innovation: Why Models of Innovation are Models, or What Work is Being Done in Calling Them Models? Working Paper No.22

Hayton, J. C., \& Kelley, D. J. (2006). A competency-based framework for promoting corporate entrepreneurship. Human Resource Management, 45(3), 407-427.

Hidalgo, A., \& Albors, J. (2008). Innovation management techniques and tools: a review from theory and practice. RED Management, 38(2), 113-127.

Kelley, T., \& Littman, J. (2006). The ten faces of innovation: IDEO's strategies for defeating the devil's advocate and driving creativity throughout your organization. Crown Business.

Kline, S. J., \& Rosenberg, N. (1986). Innovation: an overview. The positive sum strategy: harnessing technology for economic growth, Landeau R., Rosenberg N., (éds.), Academy of Engineering Press, Washington.

Leonard-Barton, D. (1995). Wellsprings of knowledge: Building and sustaining the sources of innovation. University of Illinois at Urbana-Champaign's Academy for Entrepreneurial Leadership Historical Research Reference in Entrepreneurship.

Liyanage, S. and Poon, P.S. (2002) Technology and innovation management learning in the knowledge economy. The Journal of Management Development, 22, 7/8, 579-602.

Maclaurin, W. R. (1953) The sequence from invention to innovation and its relation to economic growth. Quarterly Journal of Economics 67 (1):97-111.

Maslow, A. H. (1943). A theory of human motivation. Psychological review, 50(4), 370.

Merriam-Webster. (2016). Merriam-Webster's collegiate dictionary. Merriam-Webster.

Montoya-Weiss, M. M., and Calantone, J. R. (1994). Determinants of new product performance: A review and meta-analysis. Journal of Product Innovation Management, 11(5): 397-417.

Nordhaug, O., \& Gr $\oslash$ nhaug, K. (1994). Competences as resources in firms. International Journal of Human Resource Management, 5(1), 89-106.

Pavitt, K. (1991), "Key characteristics of the large innovating firm", British Journal of Management, Vol. 2 No. 1, pp. 41-50

Quayle M. (2009), Dstudio at UBC. Retrieved 2016-09-26 from: http://dstudio.ubc.ca/research/strategicdesign/

Rogers, E. M. (1962). Diffusion of innovations. $1^{\text {st }}$ Edition. New York. Free Press of Glencoe.

Rogers, E. M. (1993). Diffusion of innovations. $3^{\text {rd }}$ Edition. New York. 
Rogers, E. M. (1995). Diffusion of innovations. $4^{\text {th }}$ Edition. New York.

Ruttan, V. W. 1959. Usher and Schumpeter on invention, innovation, and technological change. Quarterly Journal of Economics 73 (4):596-606.

Schlegelmilch, B.B., Diamantopoulos, A. and Kreuz, P. (2003) Strategic innovation: the construct, its drivers and its strategic outcomes. Journal of Strategic Marketing, 11, 2, 117-132.

Schumpeter, J.A. (1961) The theory of economic development : an inquiry into profits, capital, credit, interest, and the business cycle, translated from the German by Redvers Opie. New York

Schmitt, N. \& Chan D. (1998). Personnel selection. Sage, Thousand Oakes

Simon, H. A. (1996). The sciences of the artificial. MIT press.

Tarde, G. (1903). The laws of imitation, trans. EC Parsons. New York: Henry, Holt.

Thieme, J. (2007). Perspective: The world's top innovation management scholars and their social capital. Journal of Product Innovation Management 24(3):214-229.

Tidd, J., Bessant, J., Pavitt, K., \& Wiley, J. (1998). Managing innovation: integrating technological, market and organizational change. Journal of Engineering and Technology Management, $15,111-113$.

Tidd, J. (2000), Measuring Strategic Competencies: Technological Market and Organizational Indicators of Innovation, Imperial College Press, London.

Van de Ven, A. H. (1986). Central problems in the management of innovation. Management science, 32(5), 590-607.

Van de Ven, A. H. et al. (1999): Research on the Management of Innovation: The Minnesota Studies, Oxford (Oxford University Press).

Van de Ven, A.H., Polley, D.E., Garud, E. and Venkataraman, S. (1999) The innovation journey. NY. Oxford University Press.

Von Hippel, E. (1976). The dominant role of users in the scientific instrument innovation process. Research policy, 5(3), 212-239.

Hippel, E., (1988). The sources of innovation. New York: Oxford University Press.

West, J., Vanhaverbeke, W., \& Chesbrough, H. (2006). Open innovation: a research agenda. Open innovation: Researching a new paradigm, 285-307.

Wilkening, E. A. (1953), Adoption of Improved Farm Practices As Related to Family Factors, AES Research Bulletin no. 183, University of Wisconsin, Madison.

Yang, P., \& Tao, L. (2012). Perspective: Ranking of the world's top innovation management scholars and universities. Journal of Product Innovation Management, 29(2), 319-331. 


\section{Biographies}

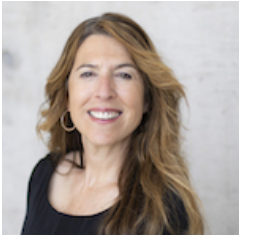

Angèle M. Beausoleil. Angèle M. Beausoleil (PhD 2016) received her BAA degree in arts and commerce from Ryerson University, Toronto, Canada in 1987 and her M.A. degree in innovation development from the University of British Columbia, Vancouver, Canada in 2013. She completed an interdisciplinary Ph.D. degree in innovation process pedagogy at the University of British Columbia (UBC), Vancouver, Canada in 2016. She is currently the assistant professor of business design and innovation at the Rotman School of Management at the University of Toronto, and a visiting lecturer of applied innovation and innovative leadership at the University of California Berkeley's Haas School of Business. From 2012 to 2016, she lectured with the UBC Sauder School of Business and led action research on design methods for business innovation. Her research interests include the design, development and delivery of human-centred design curriculum (including design thinking) inside business schools and corporations. Dr. Beausoleil's awards and honours include the Teaching Excellence Award at UC Berkeley Haas, the UBC Public Scholars Fellowship, the UBC Academic Achievement Award, the Mitacs Accelerate Internship Award(s) and Elevate Fellowship Research Award.

\section{ISSN 2183-0606}

http://www.open-jim.org

http://creativecommons.org/licenses/by/3.0 